\title{
The development of the oviducal gland in the Rajid thornback ray, Raja clavata
}

\author{
Bárbara Serra-Pereira · Fernando Afonso • Inês Farias • \\ Pedro Joyce $\cdot$ Megan Ellis (nee Storrie) $\cdot$ \\ Ivone Figueiredo $\cdot$ Leonel Serrano Gordo
}

Received: 17 August 2009 / Revised: 6 October 2010 / Accepted: 7 October 2010 / Published online: 24 October 2010

(C) Springer-Verlag and AWI 2010

\begin{abstract}
The reproductive processes of chondrichthyans are complex. Knowledge of the development and maturation of the oviducal gland is vital for understanding the reproductive biology of a species. This study represents the first contribution of this subject for skates. In the oviparous thornback ray, Raja clavata, oviducal gland development begins early in the developing stage with the formation of gland tubules and the distinct lamellae of each zone: club, papillary, baffle and terminal. Oviducal development is complete by the end of the developing stage when the storage and secretion of products is evident within the gland tubules of each zone. Periodic acid-Schiff and alcian blue histological staining showed that the secretory mucous cells of the club and papillary zones produce neutral and sulfated
\end{abstract}

Communicated by Arne Malzahn.

B. Serra-Pereira $(\square) \cdot$ I. Farias · P. Joyce · I. Figueiredo Unidade de Recursos Marinhos e Sustentabilidade, Instituto de Investigação das Pescas e do Mar (IPIMAR, INRB), Av. Brasília, 1449-006 Lisbon, Portugal

e-mail: bpereira@ipimar.pt

B. Serra-Pereira $\cdot$ P. Joyce $\cdot$ L. S. Gordo

Centro de Oceanografia \& Departamento de Biologia Animal, Faculdade de Ciências de Lisboa, Bloco C2, Campo Grande, 1749-016 Lisbon, Portugal

\section{F. Afonso}

Departamento de Sanidade Animal, Faculdade de Medicina Veterinária da Universidade Técnica de Lisboa, Av. da Universidade Técnica, Polo Universitário do Alto da Ajuda, 1300-477 Lisbon, Portugal

M. Ellis (nee Storrie)

Industry and Investment NSW, Port Stephens Fisheries Institute,

Taylors Beach, NSW 2316, Australia acid mucins. The last row of gland tubules of the papillary zone stains intensely for sulfated acid mucins. The baffle zone, which is responsible for the production of the egg capsule, represented $60-80 \%$ of the glandular zone of the oviducal gland. Sperm bundles were observed in the deeper recesses of the baffle zone during the maturation process, and during capsule extrusion, sperm were detected near the lumen. The terminal zone was composed of two types of gland tubules: serous (producing protein fibres) and mucous glands (producing sulfated acid mucins).

Keywords Maturation - Oviparous · Portugal · Rajidae · Reproduction

\section{Introduction}

The class of chondrichthyan fish includes two subclasses, the elasmobranchs (sharks, skates and rays) and the holocephalans (chimaeras). In this class, there is a great diversity of reproductive strategies including oviparity and several types of viviparity, but all share internal fertilization (Musick and Ellis 2005). Skates are oviparous and release to the sea fertilized eggs enclosed in a hard egg covering, a capsule (Musick and Ellis 2005). Embryonic development takes place inside the capsule with expense of yolk reserves. Depending on the species, the estimated incubation time lasts from 4.5 to 14 months, and for thornback ray, Raja clavata, it is approximately 5 months (Clark 1922).

Capsule formation is a process that involves an important organ of the female reproductive tract, the oviducal gland $(\mathrm{OG})$, which skates share with most chondrichthyans. The OG is derived from the oviduct and anterior to the uterus. The important physiological functions that the $\mathrm{OG}$ 
is responsible for are as follows: (1) the production of egg investments; (2) the formation of the tertiary egg coverings, including the hard egg capsule of oviparous species; (3) the transport of fertilized eggs; and (4) sperm storage in some species (Hamlett et al. 1998). Each of these functions is, in general, attributed to one of the four zones of the OG.

The OG of most chondrichthyans shares the same internal organization. The oviparous small-spotted catshark, Scyliorhinus canicula, was the first to be studied (e.g. Threadgold 1957; Rusaouën 1976; Knight et al. 1993), and most of the knowledge on the morphology and functionality of the OG was recorded from this species. In general, the $\mathrm{OG}$ is made from numerous simple gland tubules. In the tubules, secretory cells produce and secrete the materials of each zone, and these are transported through the tubules and are extruded into the lumen via secretory ducts between epithelial projections, lamellae, lining the gland lumen. The terminology for the zonation of the OG adopted in this work follows the one proposed by Hamlett et al. (1998). According to these authors, there are four distinct zones, named according to the shape of lamellae or position in the $\mathrm{OG}$, and from anterior to posterior are the club, papillary, baffle and terminal zone. The club zone is characterized by club-shaped lamellae, whereas the papillary zone has elongate digit-shaped lamellae. The baffle zone refers to the baffle plates of the spinneret region that are confluent with the secretory ducts. These plates assist with the extrusion of the capsule material into the transverse grooves that alternate with flattened plateau projections, the lamellae. The terminal zone is the most posterior zone of the gland. Terminal refers to its end position, and it is characterized by not having transverse grooves. The gland tubules are short and simple and are composed of mucous, serous or a mixture of the two types of cells (Hamlett et al. 1998, 2005).

The first step in the formation of the egg covering is the enclosure of the fertilized egg inside an egg jelly layer secreted by the club and papillary zones (Hamlett et al. 1998; Rusaouën 1976). In skates, the egg jelly leaves the capsule after approximately one-third of its development through the slits laterally located at each horn or tendril of the egg capsule, opening the capsule to embryo-assisted flow of sea water (Long and Koob 1997). The egg jelly serves as a structural device to hydrodynamically support the egg and the developing embryo, and not as a substantial source of carbohydrate nutrition for early development (Koob and Straus 1998). In addition, it is believed that the egg jelly produced by the papillary zone functions as a bonding layer and as a lubricant during encapsulation, reducing the friction between the jelly and the forthcoming capsule (Hamlett et al. 1998, 2005).

The baffle zone produces and secretes a complex material, a network of fibres that forms the tertiary egg covering. First, the proteins and enzymes enclosed in the tertiary egg covering formation are continuously produced and stored in a prepolymerized condition as storage granules that are involved by a membrane. These granules are located within the secretory cells of the gland tubules. At the final stage of the granules development, the membranes of the storage granules coalesce with the membrane of the secretory cell (at the apical surface). The granule contents are then released to the lumen of gland tubules, through a merocrine secretion process. Inside the lumen, the polymerization process, triggered by an ionic change of the environment, transforms the secreted material into coalescent strands (fibrillogenesis). The material is transported to the spinneret by ciliary action and secreted around the egg jelly surface as parallel oriented fibrils closely packed together. During the stabilization process, fibrils experience a progressive decrease in thickness with water loss and consequent increase in resistance, improving embryo's protection (Knight et al. 1993; Hamlett et al. 1998). The secreted material consists of a sulphur-containing protein called prokeratine, which is chemically close to keratin (Rusaouën 1976). In some species of sharks, the egg covering also contains collagen (Krishnan 1959). While in the uterus, the egg covering undergoes a sclerotization by quinone tanning, due to the presence of a phenolic protein (catechol) in the uterus, and an oxidation of the cathecol to quinone by the enzymes tyrosine hydroxylase and cathecol oxidase (Koob and Cox 1990, 1993; Threadgold 1957). Egg capsule morphology of oviparous chondrichthyans is species specific and offers an effective protection to the fertilized egg/ embryo due to extreme toughness and strength, flexibility, moderate extensibility and high permeability to low molecular weight substances and ions (Knight and Feng 1994a, b, 1996).

The terminal zone, the last zone of the OG, is responsible for the formation of surface hairs coated with mucous secretions that cover the exterior of the capsule in some oviparous species, like the holocephalan, Callorhynchus milli (Smith et al. 2004), and the little skate, Raja erinacea (Hamlett et al. 1998). When the oviparous egg capsule is extruded to the environment, it becomes covered with materials such as sand and other sea debris, due to the presence of the sticky hairs that serve as anchors and assist to camouflage the egg capsule (Hamlett et al. 2005). The terminal zone is also the site of sperm storage in some chondrichthyans (e.g. Fishelson and Baranes 1998; Hamlett et al. 1998, 2005; Smith et al. 2004; Storrie et al. 2008).

No previous studies have described the structural development of the skate OG, and only two researchers have investigated the development and maturation of the chondrichthyan OG (Storrie 2004, Nalini 1940). The main aim of the current study was to describe the processes underlying OG development in an oviparous Rajid, from the beginning of differentiation to the extrusion of the egg capsules. 
The nature of the secretions produced by the different gland zones at the different maturity stages was identified through histological staining techniques. The $R$. clavata is the most abundant Rajid species in the NE Atlantic (Walker and Hislop 1998); however, limited information is available about the reproductive biology of this species (e.g. Holden 1975; Walker 1999). Consequently, R. clavata was selected as a study species to better understand the process of OG development in Rajids.

\section{Materials and methods}

\section{Sampling}

The thornback ray, Raja clavata, has been routinely sampled since 2004 by the Portuguese Fisheries Institute (IPIMAR), under the scope of the National Data Collection Program (PNAB, DCR). From February 2004 to June 2008, female $R$. clavata were collected from (1) IPIMAR bottomtrawl research surveys carried out along the Portuguese continental shelf and (2) landings of commercial artisanal fleets operating with trammel nets, gillnets and longline, along northern (Matosinhos) and central (Peniche) Portugal.

For each specimen, the total length (TL) and disc width (DW) were measured (mm). The total weight (TW) $(\mathrm{g})$ was recorded. The specimen was sexed, and a maturity stage was assigned by applying the maturity scale proposed by Serra-Pereira et al. (2010) for oviparous elasmobranchs (Table 1). The oviducal glands (OG) of each specimen were removed, measured in $\mathrm{mm}$ (width, height and thickness; Fig. 1a), weighed $(0.01 \mathrm{~g})$ and preserved in $10 \%$ buffered formaldehyde. The relationship between maturity and morphometric characteristics of the OG was analysed using ANOVA and Tukey's HSD (honestly significant difference) tests.

\section{Histological procedures}

The modifications in the histological structure of the OG and the presence and nature of the secretions produced during the development process were analysed using a selection of one OG per specimen, covering all the maturity stages. Sagittal sections of about $3 \mathrm{~mm}$ thick were removed from the middle of the OGs (Fig. 1b). The samples were processed using an automated tissue processing machine (Leica TP1020, Germany). The protocol consisted of (1) dehydration through a series of alcohols from $70 \%$ to absolute ethanol; (2) clearing with xylene; and (3) impregnation and embedding in paraffin wax. Embedding of the samples in paraffin wax blocks was made using the heated paraffin embedding system (Leica EG $1140 \mathrm{H}$, Germany). The paraffin blocks were then sliced, in sagittal sections, at 3-5 $\mu \mathrm{m}$ of thickness, using a sliding microtome (Leica SM 2000 R, Germany) and a rotary microtome (Leica RM2125RT, Germany). Different staining techniques were tested to analyse the histological structure of the OG: (1) haematoxylin and eosin (H\&E), staining the nucleus black and the cytoplasm pink and (2) Toluidine blue (TB), a metachromatic dye with a blue nuclear counterstain. Additional staining procedures were used to investigate the chemical nature of the secretions produced by the different glandular zones: (1) periodic acid-Schiff (PAS), with and without diastase, used to detect neutral mucins (PAS+ structures stained pink); (2) combined alcian blue and PAS to detect sulfated acid and neutral mucins (PAS/AB) (PAS+ structures stained pink, $\mathrm{AB}+$ stained blue and $\mathrm{PAS}+\mathrm{AB}+$ stained in different intensities of purple); (3) Van Gieson stain (VG) to detect collagen, stained in red. Histological staining protocols used by Bancroft and Gamble (2002) were followed, with some adaptations to improve the results. These included: (a) in PAS and PAS/ $\mathrm{AB}$ staining techniques, sections were covered with Schiff's solution, for about 8-10 min, instead of $15 \mathrm{~min}$, since longer times caused background staining; (b) in PAS/ $\mathrm{AB}$ staining, after staining with $\mathrm{AB}$, sections were covered with $1 \%$ Periodic acid, for $3 \mathrm{~min}$, instead of $5 \mathrm{~min}$, with the same results; and (c) in VG staining, sections were covered in Van Gieson solution for $5 \mathrm{~min}$ instead of $3 \mathrm{~min}$, for more intense staining .

The histological slides were observed using a stereomicroscope (Olympus SZX9, USA) and an optic microscope (Carl Zeiss Axioplan 2 imaging, Germany). The former was used to observe the whole sagittal section of the gland, and the latter was used to analyse the in situ gland structure in more detail. Images were obtained using a Sony DFWSX910 camera and the imaging software TNPC 4.1 used with the stereomicroscope and a Zeiss AxioCam MRc camera and the imagining software AxioVision 4.1 used with the optic microscope.

AxioVision 4.1 was used to collect the detailed measurements of the OGs in different maturity stages in order to evaluate the gland structures growth with maturity. The thickness of the smooth muscular tissue layer surrounding the OG was measured. The gland tubules growth was evaluated using gland tubules diameter and wall thickness (from the lumen to the periphery) measurements. TNPC 4.1 was also used to measure several aspects of the $\mathrm{OG}$ in order to evaluate the growth and the final area occupied by each zone of the OG. For that purpose, the surface length or distance along the surface of the OG lumen lined with lamellae and the area occupied by the gland tubules, in each zone, were measured. 


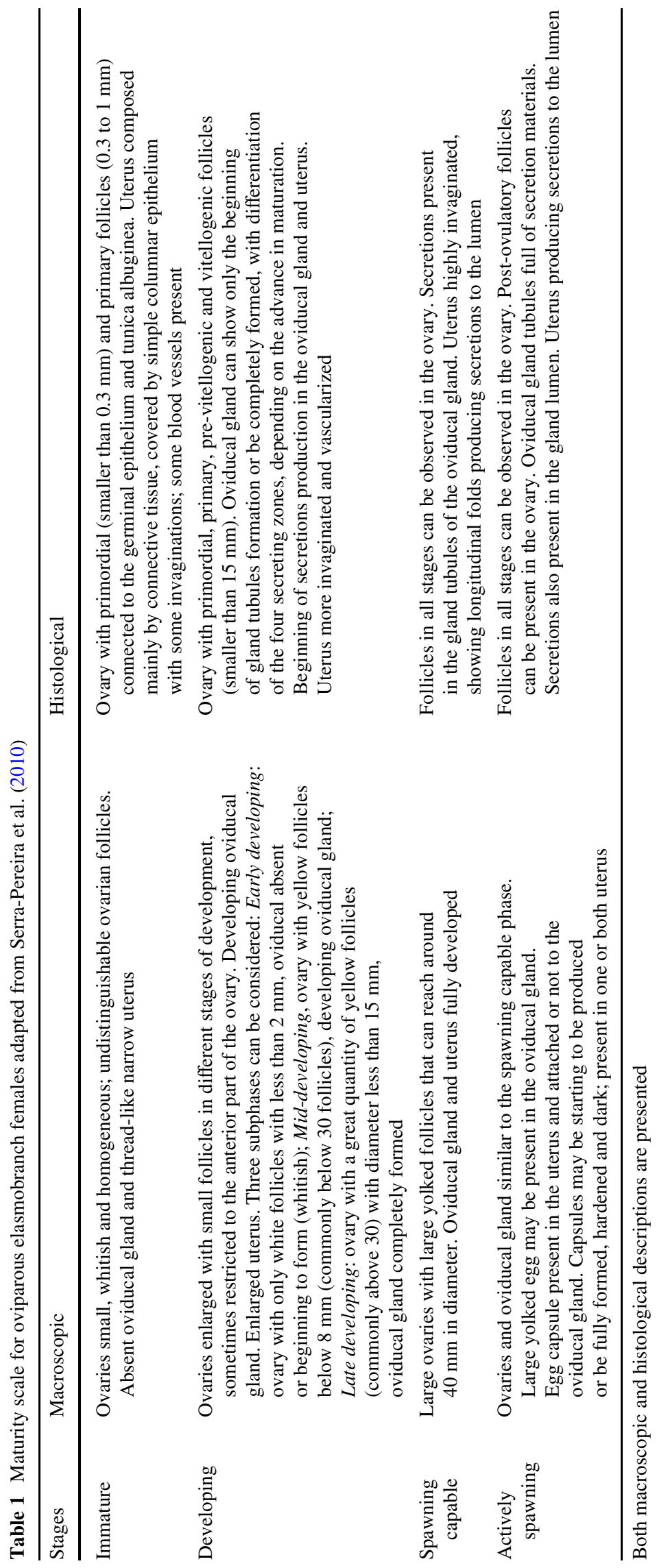



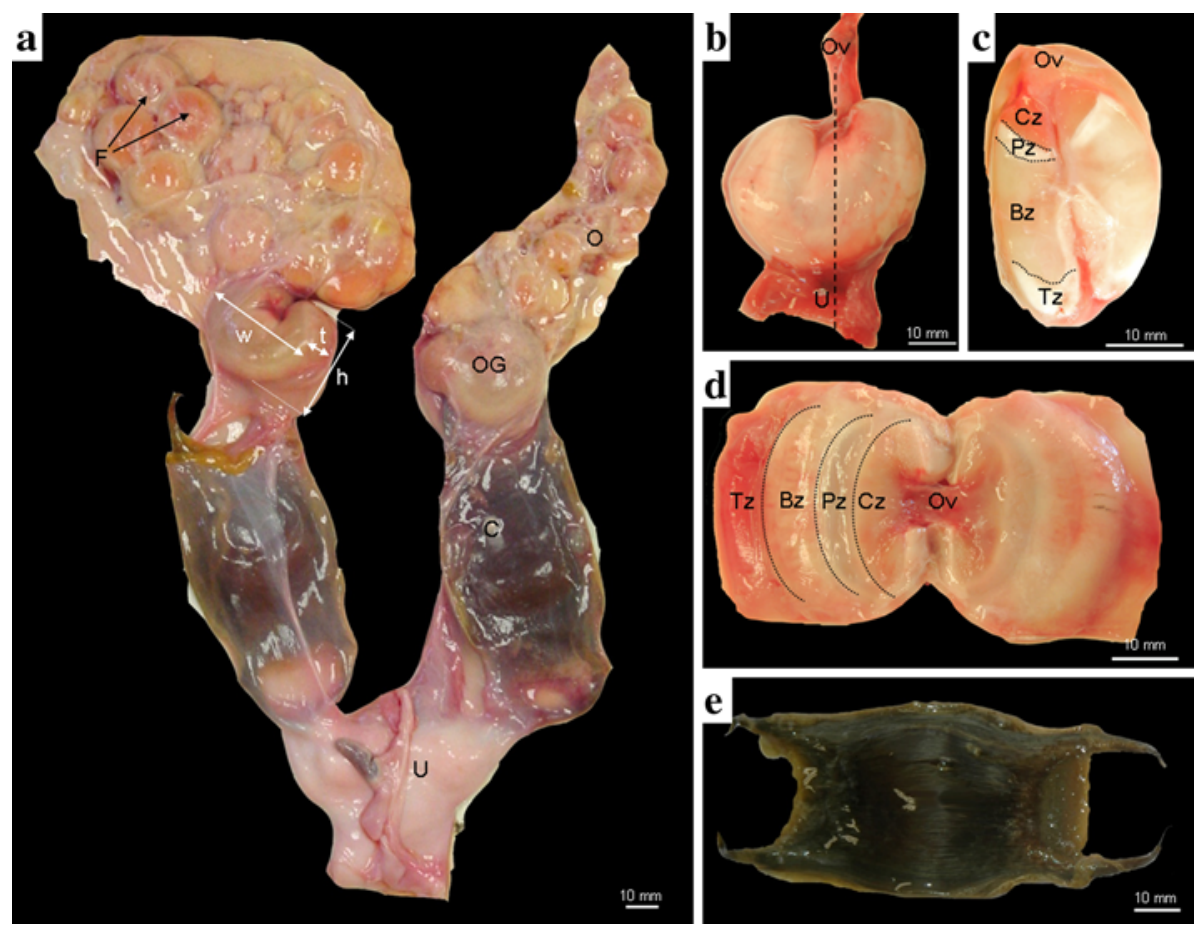

Fig. 1 a Reproductive tract of a female Raja clavata at the actively spawning stage. The measurements made on the OGs are represented: $w$ width, $h$ height, $t$ thickness. b External anatomy of the OG at the actively spawning stage. Anteriorly, the OG communicates with the oviduct, while posteriorly it communicates with the uterus. The dotted line in the centre indicates the position of sagittal sectioning. c Sagittal section of the OG at the actively spawning stage, showing the different zones from anterior to posterior: club zone; papillary zone; baffle zone;

\section{Results}

A total of 142 female Raja clavata were used for studying the development of the OG. The reduced number of females with developed oviducal gland (OG) specimens was due to an overrepresentation of immature females in landings. The female reproductive tract in the spawning stage of maturity is represented in Fig. 1a. At this stage, it was possible to observe the two ovaries filled with large yolked follicles. The OGs, located between the oviduct and the uterus, were completely formed $(40 \mathrm{~mm}$ width) at this stage (Fig. 1b). They were composed of two identical beanshaped halves surrounding a flattened lumen. The succession of the different zones from the oviduct to the anterior uterus was observed both in sagittal section (Fig. 1c) and in the frontal view, with the two halves of the OG separated (Fig. 1d). Inside the uterus, two egg capsules were in development, still flexible and without surface fibres. A fully formed capsule of $R$. clavata is shown in Fig. 1e. The capsule was rectangular in shape, dark brown in colouration with two short horns on each distal extremity, and the dorsal and ventral surfaces were covered by a high density of fibres. In most of the examples, these features made the egg capsule opaque. terminal zone. d Internal view of the two halves of the OG at the actively spawning stage, displaying the different gland zones, from the oviduct to the uterus: club zone; papillary zone; baffle zone; terminal zone. e Dorsal view of an egg capsule, the surface of which is covered with hairs. $O$ ovary, $F$ follicles, $O G$ oviducal gland, $C$ capsule, $U$ uterus, $O v$ oviduct, $C z$ club zone, $P z$ papillary zone, $B z$ baffle zone, $T z$ terminal zone

Macroscopic development

The size of the OG increased with maturity (Fig. 2a-c). In the immature stage, the OG was not differentiated, so no measurements were taken. All the morphometric characteristics (width, height and thickness) were demonstrated to be statistically different between maturity stages (Table 2). During the developing stage, the gland was visible and the values of the three measurements were the lowest of all maturity stages. Macroscopic development of the OG was completed during the spawning stage, when the median values for width, height and wall thickness were the greatest. Some overlap of OG measurement across stages occurred because females of the same TL showed great variation in OG size (Fig. 2d).

\section{Microscopic structure}

A total of 70 OGs from females at different stages of maturity were selected for histological examination. Figure 3 presents the general appearance of OG during development: (a) immature (Fig. 3a); (b) early developing (Fig. 3b); (c) mid-developing (Fig. 3c); and (d) spawning capable (Fig. 3d). 
Fig. 2 Oviducal gland (OG) measurements by maturity stage (2 developing; 3 spawning capable; 4 actively spawning): a width; b height; $\mathbf{c}$ thickness. d Relationship between OG width and the specimen total length
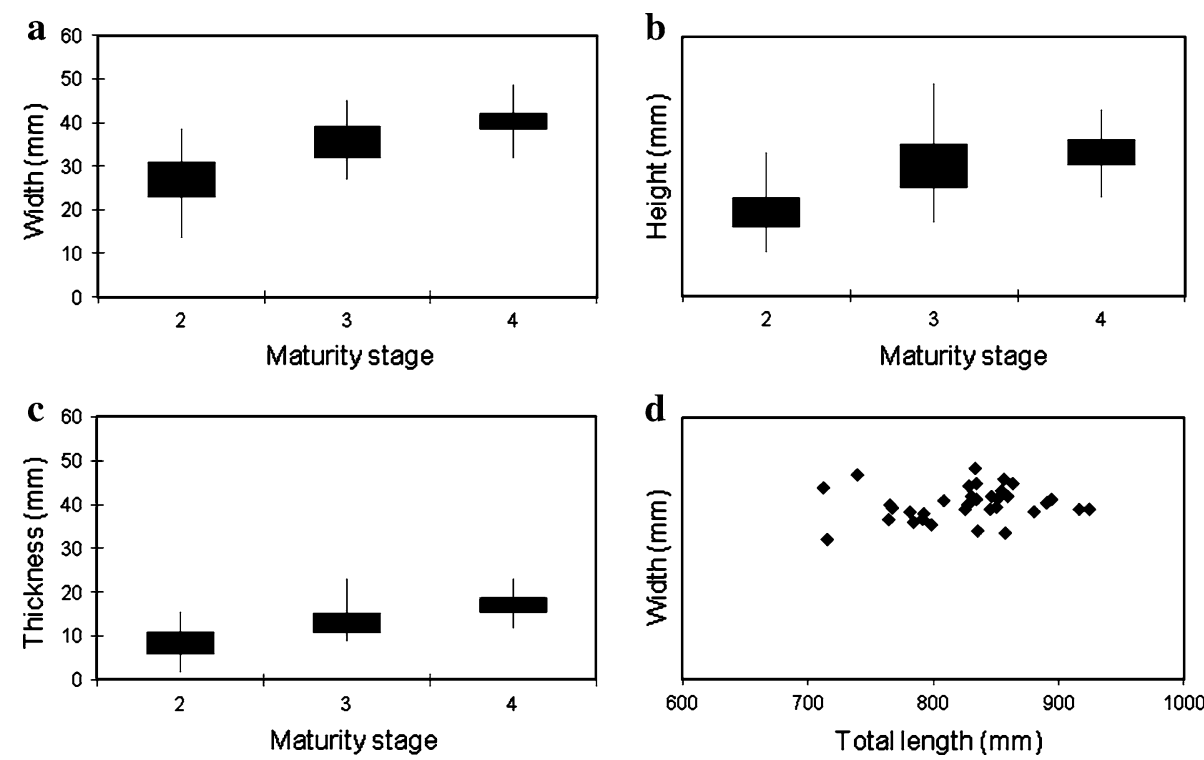

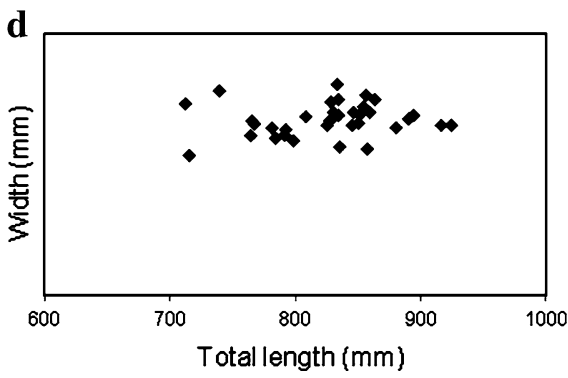

Table 2 Statistical results on the effect of maturity on the morphological characteristics of the oviducal gland (width, height and thickness)

\begin{tabular}{|c|c|c|c|c|c|c|c|c|}
\hline & \multicolumn{3}{|c|}{ ANOVA } & \multicolumn{5}{|c|}{ Tukey's HSD test } \\
\hline & \multicolumn{2}{|l|}{ All } & \multicolumn{2}{|c|}{2 vs. 3} & \multicolumn{2}{|c|}{2 vs. 4} & \multicolumn{2}{|c|}{3 vs. 4} \\
\hline & $n$ & $P$-value & $n$ & $P$-value & $n$ & $P$-value & $n$ & $P$-value \\
\hline Width & 138 & $<0.01$ & 104 & $<0.01$ & 97 & $<0.01$ & 75 & 0.01 \\
\hline Height & 138 & $<0.01$ & 104 & $<0.01$ & 97 & $<0.01$ & 75 & $<0.01$ \\
\hline Thickness & 102 & $<0.01$ & 104 & $<0.01$ & 97 & $<0.01$ & 75 & $<0.01$ \\
\hline
\end{tabular}

Maturity stages: 2 developing, 3 spawning capable, 4 actively spawning

In an immature stage, there was no visible differentiation of the OG from the rest of the reproductive tract (Fig. 3a). The region of the reproductive tract representing the OG contained some lamellae and the lumen was lined by simple columnar epithelium cells.

During the early part of the developing stage, early developing stage, the $\mathrm{OG}$ was visible as an expansion of the reproductive tract between the oviduct and uterus. Uniform lamellae were observed along the entire section of the OG (Fig. 3b). At this stage, the simple and unbranched gland tubules have started to differentiate and this differentiation began from the lumen and extended to the periphery of the gland (Fig. 3c). The gland tubules were supported by loose connective tissue that was reduced as the gland tubules proliferated throughout the OG. In the developing stage, it was possible to distinguish serous and mucous glands prior to the differentiation of the distinct lamellae of each zone. In cross section, the gland tubules had an average diameter of $57.27 \pm 11.55 \mu \mathrm{m}$ and an average wall thickness of $20.54 \pm 4.89 \mu \mathrm{m}(n=48)$. Near the gland tubules in the centre of the OG, where the baffle zone will be originated, some homogeneous brown material accumulations were sometimes visible (Figs. $4 \mathrm{a}, \mathrm{b}$ ). None of the staining techniques used in this study produced a positive result to identify the brown material. At this stage, the smooth muscular tissue layer surrounding the OG was thin and with a small number of muscular fibres $(496.42 \pm 39.61 \mu \mathrm{m})$. Staining with VG produced negative results, indicating that the OG did not contain collagen.

In the late developing stage, the OG was fully differentiated into four zones: club, papillary, baffle and terminal. The zones were identified according to the shape of the lamellae lining the lumen (first column in Fig. 5) and by the distinct secretory tubules (general appearance in the second column in Fig. 5 with cellular detail in the third column in Fig. 5). The gland tubules have become large (average diameter $74.89 \pm 7.11 \mu \mathrm{m}, n=50$ ) and their walls thick (average wall thickness $23.39 \pm 4.58 \mu \mathrm{m}, n=50$ ). The club zone had club-shaped lamellae (Fig. 5a). The surface epithelium of the lamellae, similar in the four zones, was composed of ciliated cells and secretory cells. Similarly, the gland tubules (Fig. 5b) also contained two types of cells: (a) sustentacular ciliated cells with elongated apical nuclei and (b) secretory cells with, large, globular, basal nuclei (Fig. 5c). The papillary zone had digit-shaped lamellae (Fig. 5d). Most of the gland tubules were very similar to the ones in the club zone, with the exception of the caudal-most papillary tubules, adjacent to the baffle zone, that were more vacuolated (Fig. 5e). As in the club zone, the epithelium of the tubules contained ciliated cells and secretory cells (Fig. 5f). The baffle zone had two types of epithelial projections: a pair of small folds in the spinneret region, the baffle plates, surrounded by a pair of large folds and the 
Fig. 3 Sagittal sections of the oviducal gland (OG) of Raja clavata, at the different stages of development. a Undifferentiated $\mathrm{OG}$ in an immature female.

H\&E. b Beginning of the development of the OG in an early developing female. H\&E. c Formation of lamellae, gland tubules and differentiation of the four distinct zones in a developing female. H\&E. d Fully developed OG with full differentiation of the four secretory zones in a spawning capable female. PAS/ AB. $C T$ connective tissue, $L$ lumen, $L m$ lamellae, $C z$ club zone, $P z$ papillary zone, $B z$ baffle zone, $T z$ terminal zone
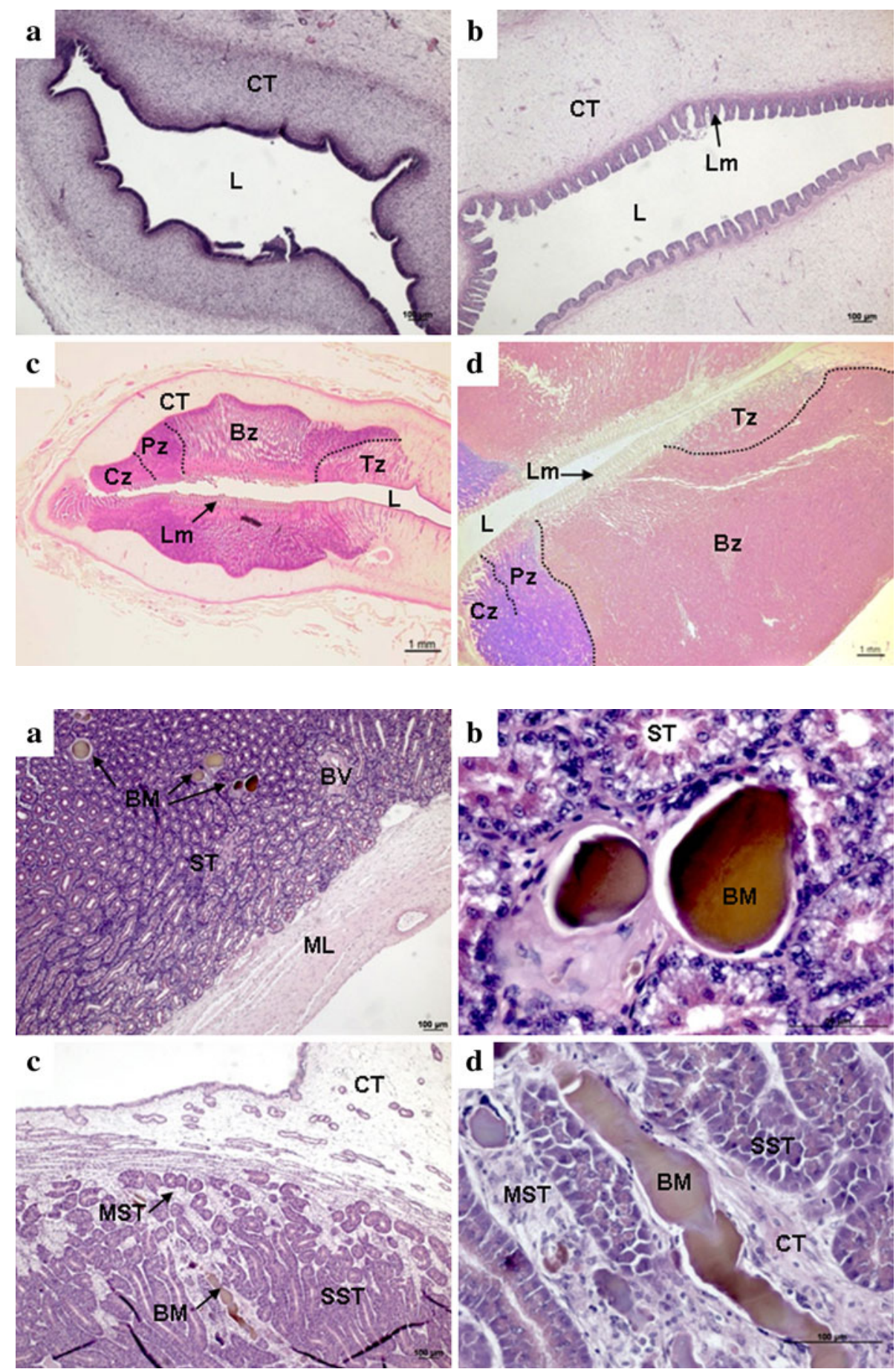

Fig. 4 Brown material accumulations. a Deep recesses of the baffle zone in a developing female. H\&E. b Detail of the brown material observed in the baffle zone in a developing female. H\&E. c Terminal zone in an actively spawning female. H\&E. d Detail of the brown material observed in the terminal zone in an actively spawning female. $B M$ brown material, $S T$ secretory tubules, $B V$ blood vessel, $M L$ muscle layer, $C T$ connective tissue, $M S T$ mucous secretory tubule, $S S T$ serous secretory tubule plateau projections (Fig. 5g). A blood vessel was observed within each plateau projection. For the baffle zone, the number of transverse grooves ranged from 25 to 30 , in each half of the lumen $(n=17)$. The epithelium of the gland tubules was composed of secretory cells and ciliated cells (Fig. 5h, i). The cytoplasm of the secretory cells was packed with numerous secretory granules (Fig. 5i). The terminal zone (Fig. $5 \mathrm{j}$ ) consisted of elongated gland tubules and a regular surface epithelium with unequal spacing of the secretory duct openings, without lamellae. Two types of gland tubules were identified, those composed of serous secretory cells (similar to those in the baffle zone) and those composed of mucous secretory cells (frothy, vacuolated cells) (Fig. 5k). Both types of gland tubules had an epithelium lining the lumen, composed of ciliated cells and secretory cells (Fig. 51).

In the spawning capable stage, the secretory tubules had thicker walls (average wall thickness $24.31 \pm 14.02 \mu \mathrm{m}$, 

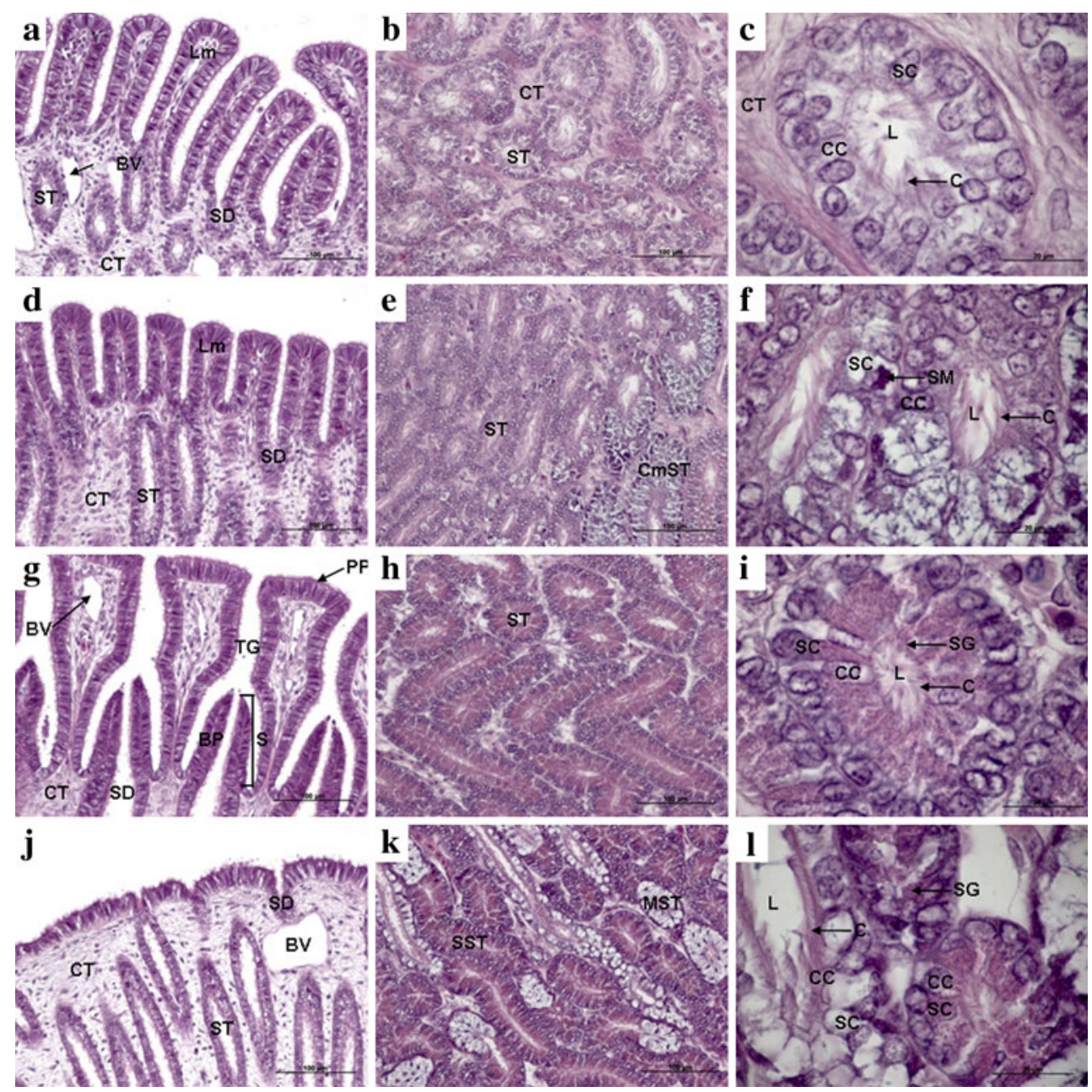

Fig. 5 Differentiated zones of the oviducal gland in the late developing stage. H\&E. a Club zone lamellae. b Club zone secretory tubules. c Detail of a secretory tubule, in the club zone, with cilated and secretory cells. d Papillary zone lamellae. e Papillary zone secretory tubules. The caudal-most papillary tubules adjacent to the baffle zone are distinct from the remaining tubules. $\mathbf{f}$ Detail of a secretory tubule, in the papillary zone, with ciliated cells and secretory cells. Secretory granules stored inside secretory cells. g Baffle zone lamellae. The secretory ducts open into the lumen through the spinneret region, composed of two baffle plates. The baffle plates are surrounded by another pair of large folds, the plateau projections, lining the transverse groove. h Baffle serous secretory tubules. i Detail of a secretory tubule, in the baffle zone, with ciliated cells and secretory cells. Secretory cells

$n=60)$ as a consequence of more secretions stored inside their cells. The granules of the secretory cells of the club zone stained PAS+ and AB+ (Fig. 6a, b). The secretory tubules of the papillary zone produced three distinct types of mucins as identified by their differential staining (Fig. 6c): (a) the majority of the tubules were PAS+ and $\mathrm{AB}+$ (Fig. 6d); (b) the region near the lumen was intensely $\mathrm{PAS}+$ (Fig. 6e), or PAS+ and AB+; and (c) the most-caudal row of secretory tubules near the baffle zone were $\mathrm{AB}+$ (Fig. 6f). The cells of the baffle zone did not react to any of contain secretory granules. $\mathbf{j}$ Structural organization of the terminal zone displaying the regular surface epithelium and the elongated tubular glands opening into the lumen. $\mathbf{k}$ Terminal zone secretory tubules, with both mucous and serous secretory cells. I Detail of the two types of secretory tubules, in the terminal zone, mucous and serous. Both tubules present ciliated cells and secretory cells. Secretory cells of serous tubules present secretory granules. $L m$ lamellae, $B V$ blood vessel, $S T$ secretory tubule, $S D$ secretory duct, $C T$ connective tissue, $S C$ secretory cell, $C C$ ciliated cell, $L$ Lumen, $C$ cilia, $C m S T$ caudal-most secretory tubules on papillary zone, $S M$ secretory material, $P P$ plateau projection, $T G$ transverse groove, $B P$ basal plate, $S$ spinneret, $S G$ secretory granules, $S S T$ serous secretory tubules, $M S T$ mucous secretory tubule

the special staining techniques tested in the present work (Fig. 6g). In some spawning capable females, the secretory tubules deep in the baffle zone (near the muscle tissue) contained almost no secretory materials. In the terminal zone, mucous glands were $\mathrm{AB}+$ and serous glands were PASand $\mathrm{AB}-$ (Fig. 6h, i). Secretions were also detected in the lumen of the gland tubules in: (a) the papillary zone (Fig. 7a); (b) the baffle zone, both in the gland tubules (Fig. 7b) and in secretory ducts (Fig. 7c); and (c) the terminal zone (Fig. 7d). 

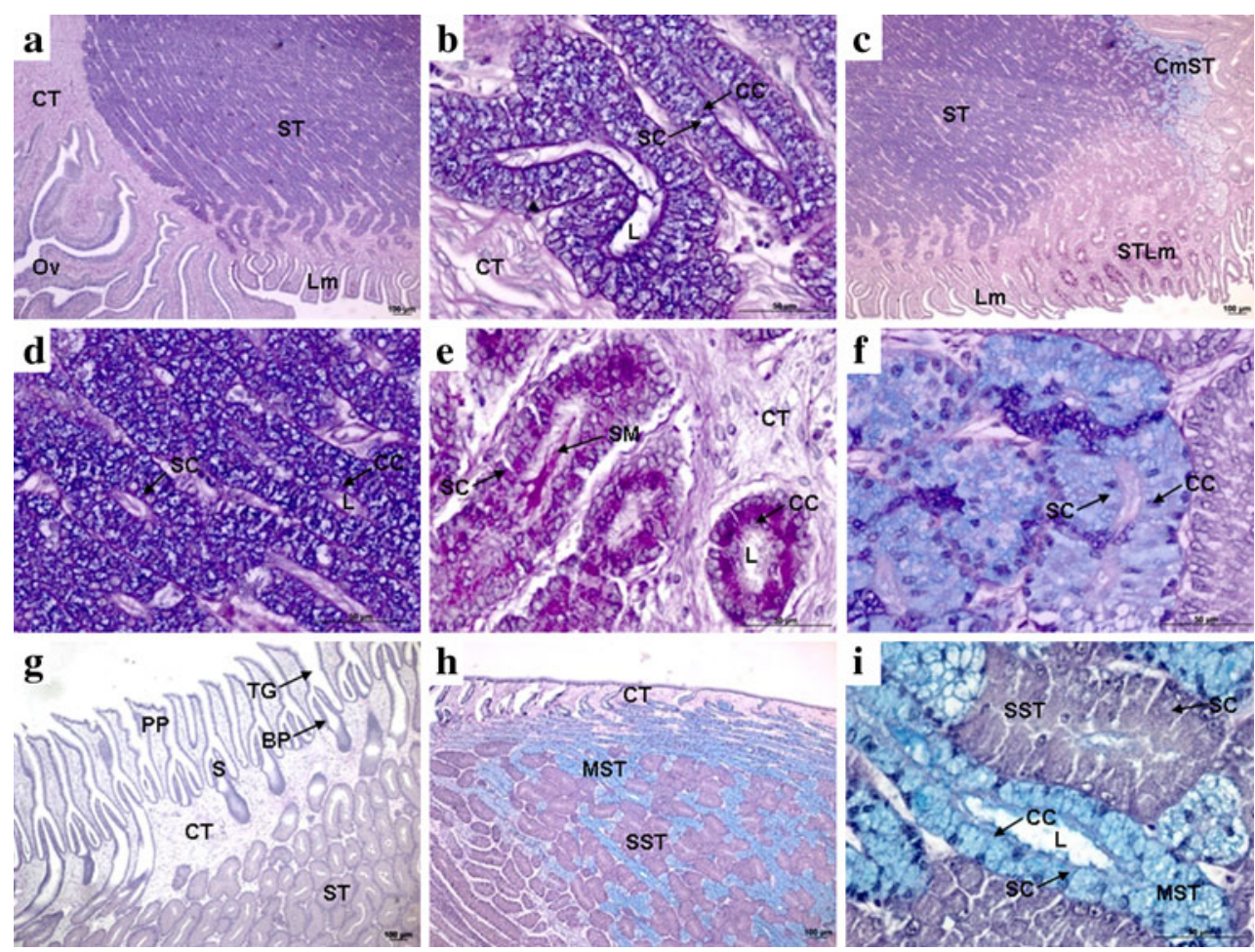

Fig. 6 Secretory material produced by the secretory tubules from the four zones of the oviducal gland of a spawning capable/actively spawning female. PAS/AB. a Club zone with PAS+ and $\mathrm{AB}+$ secretory material stored inside the tubules. $\mathbf{b}$ Secretory tubules of the club zone with $\mathrm{PAS}+$ and $\mathrm{AB}+$ secretory material stored inside the secretory cells. c Structural organization of the different regions of the papillary zone. d Secretory tubules of the papillary zone, containing PAS+ and $\mathrm{AB}+$ secretory material. e Papillary secretory tubules near the lumen containing PAS+ secretory granules. f Caudal-most papillary tubules containing $\mathrm{AB}+$ secretory material. g Baffle zone secretory tubules
$\mathrm{PAS}-$ and $\mathrm{AB}-. \mathbf{h}$ Terminal zone mucous secretory tubules containing $\mathrm{AB}+$ secretory material and serous secretory tubules PAS - and $\mathrm{AB}-$. i Mucous secretory tubules (terminal zone) containing $\mathrm{AB}+$ secretory material stored inside secretory cells. $C T$ connective tissue, $S T$ secretory tubules, $L m$ lamellae, $O v$ oviduct, $S C$ secretory cell, $C C$ ciliated cell, $L$ Lumen, STLm secretory tubules near the lamellae on papillary zone, $C m S T$ caudal-most secretory tubules on papillary zone, $S M$ secretory material, $P P$ plateau projection, $T G$ transverse groove, $B P$ basal plate, $S$ spinneret, $S S T$ serous secretory tubules, $M S T$ mucous secretory tubule
At spawning stage, the gland tubules attained the largest average sizes in diameter $94.03 \pm 14.02 \mu \mathrm{m}$ and wall thickness $43.43 \pm 8.85 \mu \mathrm{m} \quad(n=30)$. The secretory tubule lumens, closest to the lumen of the whole OG, were filled with secretions in all four zones. In spawning females, brown material accumulations were also observed, in the baffle and terminal zones (Fig. 4c, d).

\section{Presence of sperm}

Sperm were observed inside the OG of 13 females, from the developing to the actively spawning stage. Sperm were observed as laterally aligned bundles in the deep recesses of the baffle zone tubules, adjacent to the muscle layer, mainly located in the anterior portion of the baffle zone (Fig. 8a, b). These tubules containing sperm were composed of both secretory and sustentacular ciliated cells. In the spawning capable and actively spawning stages, non-aggregated individual sperm were also observed inside the gland tubules near the spinneret in the baffle zone (Fig. 8c, d).

\section{Histological measurements}

The surface length and glandular area of each zone of the OG increased in size with maturity (Fig. 9). The maximum surface length occurred earlier than the associated glandular area, which was attained only in the actively spawning stage. The surface length of the club and papillary zones each represented about $12 \%$ of the total surface length of all lamellae (Fig. 9a). The maximum surface length of the baffle zone was found in the developing stage and represented about $35 \%$ of the total surface length. Similarly, the terminal zone represented about $37 \%$ of the total surface length. When analysing the glandular growth of the different maturity stages (Fig. 9b), the baffle zone was most often the largest, occupying 60-80\% of the total glandular area. The club and papillary zones together represented 10-20\%. They were analysed together, because of the difficulty in distinguishing the limits between them. The terminal zone was the only glandular zone that decreased in relative size with maturation, from 12 to $17 \%$ in the developing stage to $5-7 \%$ in the extruding stage. 
Fig. 7 Secretory material accumulated in the tubules lumen of spawning capable females. a Papillary zone containing PAS+ secretory material. PAS/ AB. b Baffle zone tubular glands containing egg capsule material. H\&E. c Baffle zone secretory ducts secreting the egg capsule material to the gland lumen. H\&E. d Terminal zone secretory ducts secreting the surface hairs to the gland lumen. H\&E. $S T$ secretory tubule, $S M$ secretory material, $L$ Lumen, $S D$ secretory duct, $C T$ connective tissue, $E C$ egg capsule, $P P$ plateau projection, $B P$ basal plate, $S H$ surface hair

Fig. 8 Sperm observed inside the oviducal gland. H\&E. a Sperm bundles inside the tubules of the baffle zone deep in the oviducal gland, in the late developing stage. b Detail of the tubules containing sperm in the deep recesses of the baffle zone in the late developing stage. c Non-aggregated individual sperm inside the secretory ducts of the baffle zone in spawning capable females. $\mathbf{d}$ Detail of the secretory duct containing sperm, in the spawning capable stage. $M L$ muscle layer, $B V$ blood vessel, $S$ sperm, $S T$ secretory tubules, $L$ lumen, $C T$ connective tissue, $S D$ secretory duct, $B P$ basal plate, $P P$ plateau projection
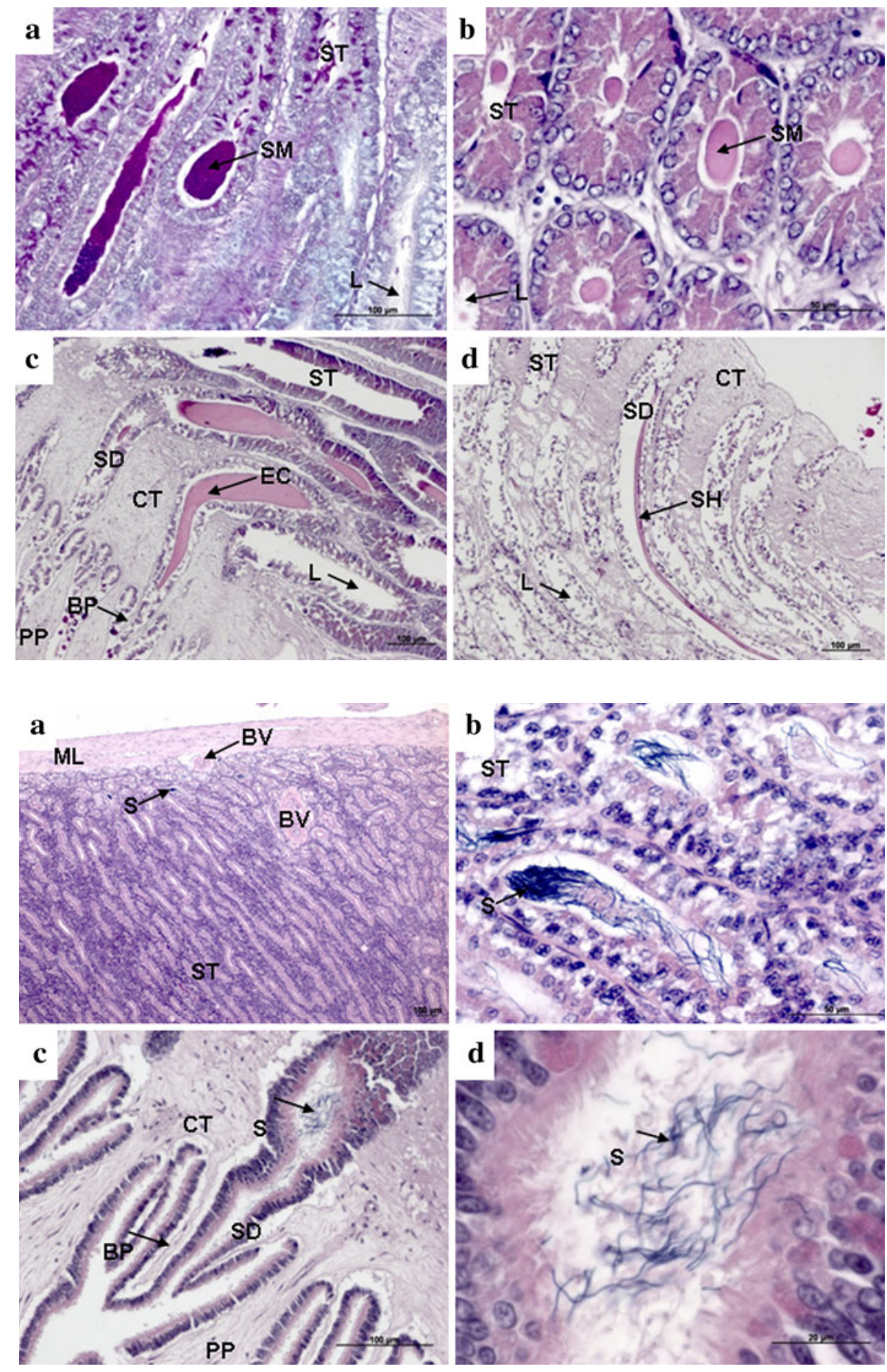

\section{Discussion}

The main morphology and functionality features of the oviducal gland (OG) are virtually identical between all chondrichthyans. Only numbfishes, a family (Narcinidae) of electric rays from the order Torpediniformes, are reported to lack this organ (Prasad 1945). Oviparous species have the largest OGs in chondrichthyans (Hamlett et al. 2005). The OG of Raja clavata is one of the biggest and is similar in size (at the actively spawning stage) to the OG from the grey bambooshark, Chiloscyllium griseum $(50 \mathrm{~mm}$ height and $38 \mathrm{~mm}$ width; Nalini 1940), and the catshark, Scyliorhinus canicula $(35 \mathrm{~mm}$ height and $20 \mathrm{~mm}$ width; Knight et al. 1996). Within the Rajidae family, the OG is virtually similar, although small histological differences could be observed (Hamlett et al. 1998). Oviparous species have species-specific egg capsules (i.e. different shape and size). In the species that have egg capsules with surface hairs 


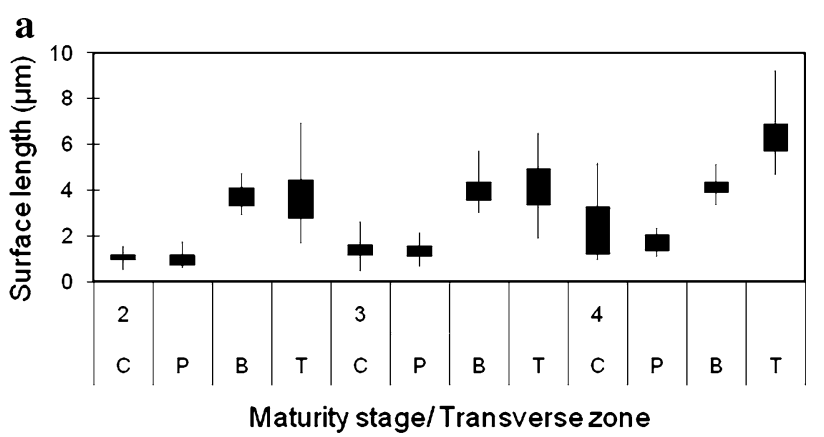

b

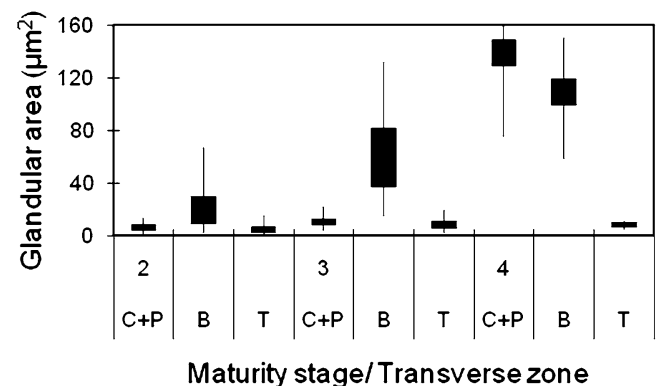

Fig. 9 Measurements of the different zones ( $C$ club, $P$ papillary, $C+P$ club and papillary, $B$ baffle, $T$ terminal) of the oviducal gland by maturity stage ( 2 developing; 3 spawning capable; 4 actively spawning). a Surface length $(\mu \mathrm{m})$. b Glandular area $\left(\mu \mathrm{m}^{2}\right)$. Boxes limit the percentiles 25 and 75. Bars stands for the upper and lower value observed

(e.g. R. clavata, Raja erinacea and Raja eglanteria), the terminal zone possesses both mucous and serous glands, while the latter are absent from those species with smooth egg capsules, like S. canicula (Knight et al. 1996; Hamlett et al. 2005).

This study is the first to describe the OG development throughout the reproductive maturation of skates. In developing $R$. clavata females, mucins were first visualized in the club, papillary and terminal zones. Therefore, it could be concluded that this stage is when the secretory cells of the gland tubules start to produce secretion materials, since prior to this stage (immature stage) no oviducal gland development was even observed. In the spawning capable stage, the secretory tubules enlarge as a result of the increase in size and number of the secretory granules stored inside the secretory cells. Later, the secretory material is released into the lumen of the gland tubules and is transported through the tubules by ciliary action of the ciliated cells in the tubule epithelium. The secretory material is transformed from secretory granules into a coalescent strand within the tubular lumen and is visible in every zone of the $R$. clavata OG. When the coalescent strands pass through the spinneret regions of the baffle zone, they become ribbon like in form and are integrated in the network of packed fibrils that will compose the future egg capsule (Knight et al. 1993).
The chemical nature of the secretions produced by the different gland zones was investigated using special histological staining techniques. The secretions of the club, papillary and terminal zones all contained mucins. In spawning capable females, the gland tubules from the club and papillary zones were filled with neutral and sulfated acid mucins, which stained positively with PAS and AB. In the papillary zone, three distinct areas were identified: (a) one area showed similar staining as the club zone, PAS+ and AB+, and included the majority of the papillary gland tubules; (b) another area close to the lamellae contained many neutral mucins that stained intensely with PAS+, and (c) the third area was located close to the junction with the baffle zone and produced sulfated acid mucins that markedly stained with $\mathrm{AB}+$.

Most of the jelly produced by the papillary zone seemed to have a final major input of neutral mucins by the second type of gland tubules, which could influence the final viscosity of the secreted product. In fact, according to Koob and Straus (1998), the jellies produced by the club and papillary zones showed different viscosities, the latter being more viscous than the layer of jelly closest to the egg. The differential viscosity resulted from a different chemical composition, with higher concentrations of galactosamine, glucosamine, galactose and fucose, and consequent higher viscosity inside the horns (egg jelly produced by the papillary zone), and lower concentration and lower viscosity near the egg (egg jelly produced by the club zone). Future studies need to focus on where and in what quantities each of these four carbohydrates are produced in the club and papillary zones, to fully understand the dynamic of the oviducal gland. In the papillary zone, the secretory material produced in the last row of tubules showed a different chemical composition (only sulphated acid mucins) from the material produced in the remaining tubules. This feature was already described to occur in oviparous species, like C. griseum (Nalini 1940) and Callorhynchus milli (Smith et al. 2004), and in viviparous species, like Mustelus antarticus (Storrie 2004). It is believed that the thin layer of egg jelly, produced by the caudal-most papillary tubules, functions as a bonding layer and lubricant between the egg investments secreted by the club and papillary zones, and the egg envelop secreted by the baffle zone (Nalini 1940).

The larger number of transverse grooves in the baffle zone provides for a thicker egg covering (Knight et al. 1993; Hamlett et al. 1998). In general, oviparous species, like $R$. clavata (25-30 transverse grooves; present study), C. griseum (74 transverse grooves; Nalini 1940) and S. canicula (20 transverse grooves; Hamlett et al. 2005) have more transverse grooves than viviparous species. In the aplacental viviparous spiny dogfish, Squalus acanthias, the baffle zone has considerably fewer transverse grooves (number not provided by the authors), and consequently, 
the egg covering is reduced to a flexible egg candle that surrounds the embryos and disappears prior to parturition. The baffle zone is completely absent in the aplacental viviparous yellow spotted stingray, Urolophus jamaicensis, and no egg covering is produced (Hamlett et al. 1998). Besides the differences in structure, the secretory cells of chondrichthyan baffle zone may also produce secretory material with different chemical compositions. In the present study, the secretory material produced by the baffle zone was not identified as one of the mucins tested in $R$. clavata OG. Yet the observation of secretory cells with the cytoplasm packed with numerous spherical granules about $1.22 \mu \mathrm{m}$ in diameter, which is characteristic of cells specializing in protein secretion (Knight et al. 1993; Junqueira and Carneiro 1995), suggests that the secretions produced in the baffle zone were proteins, as described for other species (Knight et al. 1993; Koob and Cox 1993). Studies on the OG of $R$. erinacea showed that the six major proteins, present in the granules, all contain high levels of glycine, serine, proline and tyrosine (Koob and Cox 1993). The application of Van Gieson stain showed further that the granules were not composed of collagen. This constituent was also absent in $R$. erinacea but present in the egg covering of oviparous sharks, such as S. canicula (Knight et al. 1993) and C. griseum (Krishnan 1959).

The chemical nature of the homogeneous brown material observed in the baffle and terminal zones could not be identified. No positive results were obtained for each of tested staining techniques. Despite being observed in a very early stage of the gland development, the texture and colour of these accumulations are similar to the tanned egg covering (Koob and Cox 1990, 1993; Threadgold 1957). Egg envelope material was observed emerging into the lumen from the baffle zone tubules in M. antarticus (Storrie 2004).

Sperm storage in female chondrichthyans, particularly sharks and holocephalans, has been largely confirmed by histological analysis (e.g. in the Oman shark, Iago omanensis-Fishelson and Baranes 1998; in C. milli-Smith et al. 2004; in M. antarticus - Storrie et al. 2008). Sperm storage occurs inside specialized tubules (sperm storage tubules) located in the terminal zone. The secretory cells present in the sperm storage tubules produced secretions that contributed to the support, nourishment and maintenance of the sperm during the storage period (Hamlett et al. 2002; Storrie 2004; Storrie et al. 2008). The tubules also contained ciliated cells, which are responsible for the transport of sperm into and out of the tubules.

In the case of Rajids, sperm has been histologically detected as non-aggregated, individual sperm in the baffle zone near the gland lumen and rarely in the deeper regions of the gland of $R$. erinacea (Hamlett et al. 1998). Sperm storage has been experimentally inferred through female specimens of the blonde ray, Raja brachyura (Clark 1922) and of R. clavata (Ellis and Shackley 1995) kept in captivity. In the two experiments, females were isolated from males and were able to lay fertilized eggs after 5 ( $R$. brachyura) and 13 (R. clavata) weeks of isolation.

In the present study on the OG of $R$. clavata, small groups of sperm were occasionally found in the tubules of the baffle and terminal zones near the lamellae, and more frequently, sperm bundles were observed in the tubules at the deep recesses of the baffle zone. The presence of sperm in the baffle zone of developing females indicates that mating occurs before maturity is reached, which was also reported in other chondrichthyans (e.g. M. antarticus, Storrie 2004; Storrie et al. 2008). The baffle tubules containing sperm bundles, which is a sperm aggregation characteristic of sperm storage tubules (Hamlett et al. 1998, 2002, 2005; Storrie 2004; Storrie et al. 2008), have both secretory and ciliated cells. In $R$. clavata, the secretory function may only be related to egg capsule secretion rather than to sperm maintenance because the tubules and secretory cells resemble those in the entire baffle zone and were not surrounded by highly vascularized connective tissue, a main sperm storage tubule characteristics described in previous studies (e.g. Hamlett et al. 2005; Storrie et al. 2008). Thus, the sperm observed could be the result of a recent mating episode and not from sperm that was stored for an extended period of time. Hence, further studies should be conducted to widen the observations made in the present study on $R$. clavata and to other Rajid species in order to investigate the explanation for the sperm storage facts reported in previous studies that were based on pregnant captive females (Clark 1922; Ellis and Shackley 1995).

In $R$. clavata, the terminal zone seems only to be responsible for the formation of hair filaments on the surface of the capsule and is not involved with sperm storage. As observed, this zone is composed of mixed gland tubules (two different types of gland tubules) that contain both mucous and serous glands. First, the mucous section of the tubules produces secretions, and then as the emerging hair filaments, produced by the serous glands, pass through the mucoid region, they gain a coat of sticky material that will serve the purpose of attaching debris for camouflage (Hamlett et al. 2005). In aplacental species, the terminal zone is only composed of mucous glands and SSTs (Hamlett et al. 1998). As described for other chondrichthyans (e.g. Smith et al. 2004; Hamlett et al. 2005), the terminal zone is generally not organized into lamellae. Instead, it consists of isolated, scattered tubules, which, in the case of species that have egg capsules with surface hairs it determines the positioning of those hairs. In the case of the $R$. clavata that produces an egg capsule full of surface hairs, the terminal zone is much extended in terms of its surface.

In conclusion, the formation of the egg capsule in $R$. clavata is a continuous process involving the oviducal 
gland. Capsule formation starts at the developing stage, when the OG becomes completely formed and all four zones begin to produce and secrete the relevant materials. The sperm, observed inside the tubules of the baffle zone from developing to actively spawning females, was not sperm storage. Some questions remain to be answered about the chemical nature of the secretions produced by the OG and need future investigation. Given the complexity and variability of the reproductive strategies among chondrichthyans, it would be important to expand this histological investigation to other species in order to better understand their life cycles.

Acknowledgments We thank Dr. Beverly J. Macewicz for their valued suggestions for improvement, by revising the English and the scientific content of the manuscript. We would like to acknowledge the histology technician Rosário Jorge from the Faculty of Veterinary Medicine for teaching and helping with the histological procedures, especially the staining techniques. Additionally, we would also like to thank Ana Neves from FCUL/DBA and João Oliveira and Carmo Silva from IPIMAR for preparing some of the histological slides. This study was partially supported by project EU Data Collection/, DCR (PNAB). $B$. Pereira was funded by grant from the Fundação para a Ciência e a Tecnologia, SFRH/BD/23777/2005.

\section{References}

Bancroft J, Gamble M (2002) Theory and practice of histological techniques, 5th edn. Churchill Livingstone, Elsevier, London

Clark RS (1922) Rays and skates (Raiae). No. I-Egg capsules and young. J Mar Biol Assoc UK 12:577-643

Ellis J, Shackley SE (1995) Observations on egg-laying in the thornback ray. J Fish Biol 46:903-904. doi:10.1111/j.1095-8649.1995. tb01613.x

Fishelson L, Baranes A (1998) Observations on the Oman shark, Iago omanensis (Triakidae), with emphasis on the morphological and cytological changes of the oviduct and yolk sac during gestation. J Morphol 236:151-165. doi:10.1002/(SICI)1097-4687(199806) 236:3<151:AID-JMOR1>3.0.CO;2-6

Hamlett WC, Knight DP, Koob TJ, Jezior M, Luong T, Rozycki T, Brunette N, Hysell MK (1998) Survey of oviducal gland structure and function in elasmobranchs. J Exp Zool 282:399-420. doi:10.1002/(SICI)1097-010X(199811/12)282:4/5<399:AID-JEZ 2>3.0.CO;2-6

Hamlett WC, Musick JA, Hysell CK, Sever DM (2002) Uterine epithelial-sperm interaction, endometrial cycle and sperm storage in the terminal zone of the oviducal gland in the placental smoothhound, Mustelus canis. J Exp Zool 292:129-144. doi:10.1002/jez.1149

Hamlett WC, Knight DP, Pereira FTV, Steele J, Sever DM (2005) Oviducal gland in chondrichthyans. In: Hamlett WC (ed) Reproductive biology and phylogeny of chondrichthyans: Sharks, Batoids and Chimaeras, vol 3. Science Publishers Inc, New Hamphire, pp 301-335

Holden MJ (1975) The fecundity of Raja clavata in British waters. ICES J Mar Sci 36:110-118. doi:10.1093/icesjms/36.2.110

Junqueira LC, Carneiro J (1995) Histologia Básica, 8th edn. GuanabaraKoogan, Rio de Janeiro

Knight DP, Feng D (1994a) Interaction of collagen with hydrophobic protein granules in the egg capsule of the dogfish, Scyliorhinus canicula. Tissue Cell 26:155-167
Knight DP, Feng D (1994b) Some observations on the collagen fibrils of the egg capsule of the dogfish, Scyliorhinus canicula. Tissue Cell 26:384-401

Knight DP, Feng D, Stewart M, King E (1993) Changes in macromolecular organization in collagen assemblies during secretion in the nidamental gland and formation of the egg capsule wall in the dogfish Scyliorhinus canicula. Philos Trans R Soc Lond B Biol Sci 341:419-436

Knight DP, Feng D, Stewart M (1996) Structure and function of the selachian egg case. Biol Rev 76:81-111. doi:10.1111/j.1469185X.1996.tb00742.x

Koob TJ, Cox DL (1990) Introduction and oxidation of cathecols during the formation of the skate (Raja erinacea) egg capsule. J Mar Biol Assoc UK 70:395-411

Koob TJ, Cox DL (1993) Stabilization and sclerotization of Raja erinacea egg capsule proteins. Environ Biol Fishes 38:151-157. doi:10.1007/BF00842911

Koob TJ, Straus JW (1998) On the role of egg jelly in Raja erinacea egg capsule. Bull Mt Desert Is Biol Lab 37:117-119

Krishnan G (1959) Histochemical studies on the nature and formation of egg capsules of the shark Chiloscyllium griseum. Biol Bull 117:298-307

Long JH, Koob TJ (1997) Ventilating the skates egg capsule: the transitory tail pump of embryonic little skates (Raja erinacea). Bull Mt Desert Is Biol Lab 36:117-119

Musick JA, Ellis JK (2005) Reproductive evolution of chondrichthyans. In: Hamlett WC (ed) Reproductive biology and phylogeny of chondrichthyans: Sharks, Batoids and Chimaeras, vol 3. Science Publishers Inc, New Hamphire, pp 45-79

Nalini MKP (1940) Structure and function of the nidamental gland of Chiloscyllium griseum (Mull and Henle). Proc Indian Acad Sci 12:189-214. doi:10.1007/BF03049107

Prasad RR (1945) The structure, phylogenetic significance and function of the nidamental glands of some elasmobranchs of the Madras Coast. Proc Nat Inst Sci India 11:282-303

Rusaouën M (1976) The dogfish shell gland, a histochemical study. J Exp Mar Biol Ecol 23:267-283

Serra-Pereira B, Figueiredo I, Gordo LS (2010) Application of a new reproductive terminology for teleosts to the maturation process of oviparous elasmobranchs-the case-study of the thornback ray, Raja clavata. Marine and Coastal Fisheries: Dynamics, Management, and Ecosystem Science

Smith RM, Walker TI, Hamlett WC (2004) Microscopic organization of the oviducal gland of the holocephalan elephant fish, Callorhynchus milii. Mar Freshw Res 55:155-164. doi:10.1071/ MF01078

Storrie MT (2004) Microscopic modifications of the female reproductive tissues of Mustelusantarticus. PhD thesis. School of Ecology and Environment, Deakin University

Storrie MT, Walker TI, Laurenson LJ, Hamlett WC (2008) Microscopic organization of the sperm storage tubules in the oviducal gland of the female gummy shark (Mustelus antarcticus), with observations on sperm distribution and storage. J Morphol 269:1308-1324. doi:10.1002/jmor.10646

Threadgold LT (1957) A histochemical study of the shell gland of Scyliorhinus caniculus. J Histochem Cytochem 5:159-166

Walker PA (1999) Fleeting images—dynamics of North Sea ray populations. PhD thesis. Faculty of Biology, University of Amsterdam

Walker P, Hislop J (1998) Sensitive skates or resilient rays? Spatial and temporal shifts in ray species composition in the central and north-western North Sea between 1930 and the present day. ICES J Mar Sci 55:392-402. doi:10.1006/jmsc.1997.0325 